\title{
Water-Soluble Aza-BODIPYs: biocompatible organic dyes for high contrast in vivo NIR-II imaging
}

Amélie Godard ${ }^{\mathrm{a}}$, Ghadir Kalot ${ }^{\mathrm{b} \sharp}$, Jacques Pliquett ${ }^{\mathrm{a}}$, Benoit Busser ${ }^{\mathrm{b}-\mathrm{c}}$, Xavier Le Guével ${ }^{\mathrm{b}}$, K. David Wegner $^{\mathrm{d}}$, Ute Resch-Genger ${ }^{\mathrm{d}}$, Yoann Rousselin ${ }^{\mathrm{a}}$, Jean-Luc Coll ${ }^{\mathrm{b}}$, Franck Denat ${ }^{\mathrm{a}}$, Ewen Bodio $^{\mathrm{a}^{*}}$, Christine Goze ${ }^{\mathrm{a}: *}$, Lucie Sancey ${ }^{\mathrm{b} *^{*}}$.

(a) Institut de Chimie Moléculaire de l'Université de Bourgogne, UMR 6302, CNRS, Université Bourgogne Franche-Comté, 21000 Dijon, France. (b) Institute for Advanced Biosciences, UGA INSERM U1209 CNRS UMR5309, 38000 Grenoble, France. (c) Grenoble Alpes University Hospital, 38042 Grenoble, France. (d) BAM Federal Institute for Materials Research and Testing, Richard-Willstaetter-Str. 11, 12489 Berlin, Germany.

\section{ESI Part}

\section{Experimental Part}

\section{Materials and Methods}

Reactions were carried out in analytical reagent grade solvents from Carlo Erba under normal atmosphere. Non-stabilized dry solvents were purchased from Carlo Erba and dried using a MB-SPS-800 (MBraun) or PureSolv-MD-5 (Inert®). All other reagents were purchased from Sigma Aldrich ${ }^{\mathrm{TM}}$ or ACROS Organics ${ }^{\mathrm{TM}}$ and used as received without further purification. Reactions were monitored by thin-layer chromatography and RP-HPLC-MS. Analytical thinlayer chromatography was performed with Merck 60 F254 silica gel (precoated sheets, $0.2 \mathrm{~mm}$ thick). Column chromatography was carried out using silica gel (Sigma Aldrich; 40-63 $\mu \mathrm{m} 230$ 400 mesh $60 \AA \AA)$.

$\left({ }^{1} \mathrm{H},{ }^{13} \mathrm{C},{ }^{11} \mathrm{~B},{ }^{19} \mathrm{~F}\right)$ were recorded at $300 \mathrm{~K}$ on Bruker 500 Avance III. Chemical shifts are given relative to $\mathrm{TMS}\left({ }^{1} \mathrm{H},{ }^{13} \mathrm{C}\right), \mathrm{BF}_{3}{ }^{*} \mathrm{Et}_{2} \mathrm{O}\left({ }^{11} \mathrm{~B}\right), \mathrm{CFCl}_{3}\left({ }^{19} \mathrm{~F}\right)$ and were referenced to the residual solvent signal. High-resolution mass spectra were recorded on a Thermo LTQ Orbitrap XL ESI-MS spectrometer. NMR and Mass-analyses were performed at the "Plateforme d'Analyse Chimique et de Synthèse Moléculaire de l'Université de Bourgogne" (PACSMUB).

HPLC-MS analyses were performed on a Thermo-Dionex Ultimate 3000 instrument (pump + autosampler at $20^{\circ} \mathrm{C}+$ column oven at $25^{\circ} \mathrm{C}$ ) equipped with a diode array detector (ThermoDionex DAD 3000-RS) and a MSQ Plus single quadrupole mass spectrometer equipped with a Phenomenex Kinetex® column (2.6 um C18 100 A, LC Column 50 x 2.1 mm).

The employed gradient for analyses is the following: 


\begin{tabular}{|c|c|c|c|}
\hline $\begin{array}{l}\text { Time } \\
\text { [min] }\end{array}$ & $\begin{array}{c}\% \\
\mathrm{H}_{2} \mathrm{O}+0.1 \% \\
\text { formic acid }\end{array}$ & $\begin{array}{c}\% \\
\mathrm{ACN}+0.1 \% \\
\text { formic acid }\end{array}$ & $\begin{array}{c}\text { Flow } \\
{[\mathrm{mL} / \mathrm{min}]}\end{array}$ \\
\hline 0 & 95 & 5 & 0.5 \\
\hline 5 & 0 & 100 & 0.5 \\
\hline 6.5 & 0 & 100 & 0.5 \\
\hline 6.6 & 95 & 5 & 0.5 \\
\hline 8.5 & 95 & 5 & 0.5 \\
\hline 8.51 & 95 & 5 & 0.05 \\
\hline
\end{tabular}

Semi preparative separations were executed on a HPLC-system from Shimadzu equipped with 2 LC-20AT pumps, a SPD-20A UV/Vis detector, a FRC-10A fraction collector, a SIL-10AP sampler, and a CBM-20A control unit. The column was a Shim-Pack GIST 5 um C18 10x250 $\mathrm{mm}$ column.

The gradient that was used for purifications (unless mentioned otherwise) is the following:

\begin{tabular}{|c|c|c|c|}
\hline $\begin{array}{l}\text { Time } \\
\text { [min] }\end{array}$ & $\begin{array}{c}\% \\
\mathrm{H}_{2} \mathrm{O}+0.1 \% \text { TFA }\end{array}$ & $\begin{array}{c}\% \\
A C N+0.1 \% \text { TFA }\end{array}$ & $\begin{array}{c}\text { Flow } \\
\text { [mL/min] }\end{array}$ \\
\hline 0 & 75 & 25 & 5 \\
\hline 5 & 75 & 25 & 5 \\
\hline 25 & 0 & 100 & 5 \\
\hline 28 & 0 & 100 & 5 \\
\hline 30 & 75 & 25 & 5 \\
\hline
\end{tabular}




\section{Synthesis}

Aza-SWIR-01 was synthesized by adapting reported procedures ${ }^{1}$. The analytical data of AzaSWIR-01 and of its precursors are in agreement with those previously reported. Substitution of the fluorine atom on the boron center follows the method we previously reported ${ }^{2}$.

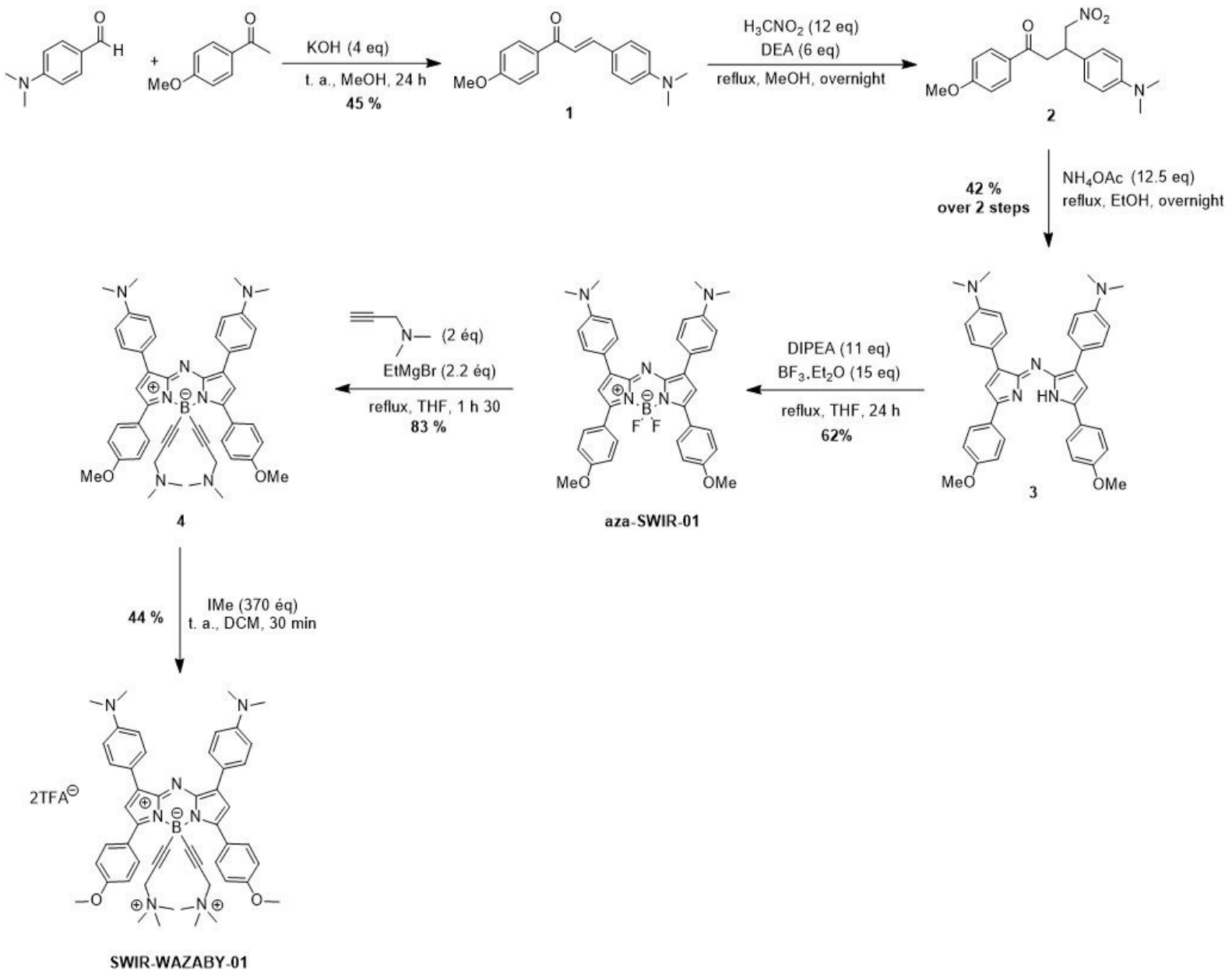

Figure S1: Synthesis of SWIR-WAZABY-01 
(E)-3-(4-dimethylaminophenyl)-1-methoxyphenylprop-2-en-1-one (1): $\mathrm{KOH}$ (7.52 g, 134.0 mmol, 4 eq) was dissolved in $100 \mathrm{~mL}$ of $\mathrm{MeOH}$ in a $500 \mathrm{~mL}$ round bottom flask. 4methoxyacetophenone $(5.00 \mathrm{~g}, 33.3 \mathrm{mmol}, 1 \mathrm{eq})$ and 4-dimethylaminobenzaldehyde $(5.00 \mathrm{~g}$, $33.5 \mathrm{mmol}, 1 \mathrm{eq}$ ) were added successively and the resulting solution was stirred at room temperature. After $24 \mathrm{~h}$ the reaction was stopped, the formed precipitate was filtered and washed with $\mathrm{MeOH}(80 \mathrm{~mL})$ to isolate pure 1 as a yellow solid $(4.24 \mathrm{~g}, 45 \%$ yield).

${ }^{1} \mathrm{H}$ NMR $\left(500 \mathrm{MHz}, 298 \mathrm{~K}, \mathrm{CDCl}_{3}\right) \delta(\mathrm{ppm})=3.04\left(\mathrm{~s}, 6 \mathrm{H}, \mathrm{H}_{\mathrm{a}}\right), 3.89\left(\mathrm{~s}, 3 \mathrm{H}, \mathrm{H}_{\mathrm{h}}\right), 6.70(\mathrm{~d}, J=8.9$ $\left.\mathrm{Hz}, 2 \mathrm{H}, \mathrm{H}_{\mathrm{b}}\right), 6.97\left(\mathrm{~d}, J=8.9 \mathrm{~Hz}, 2 \mathrm{H}, \mathrm{H}_{\mathrm{g}}\right), 7.35\left(\mathrm{~d}, J=15.4 \mathrm{~Hz}, 1 \mathrm{H}, \mathrm{H}_{\mathrm{e}}\right), 7.55(\mathrm{~d}, J=8.8 \mathrm{~Hz}, 2 \mathrm{H}$, $\left.\mathrm{H}_{\mathrm{c}}\right), 7.79\left(\mathrm{~d}, J=15.4 \mathrm{~Hz}, 1 \mathrm{H}, \mathrm{H}_{\mathrm{d}}\right), 8.03\left(\mathrm{~d}, J=8.9 \mathrm{~Hz}, 2 \mathrm{H}, \mathrm{H}_{\mathrm{f}}\right)$

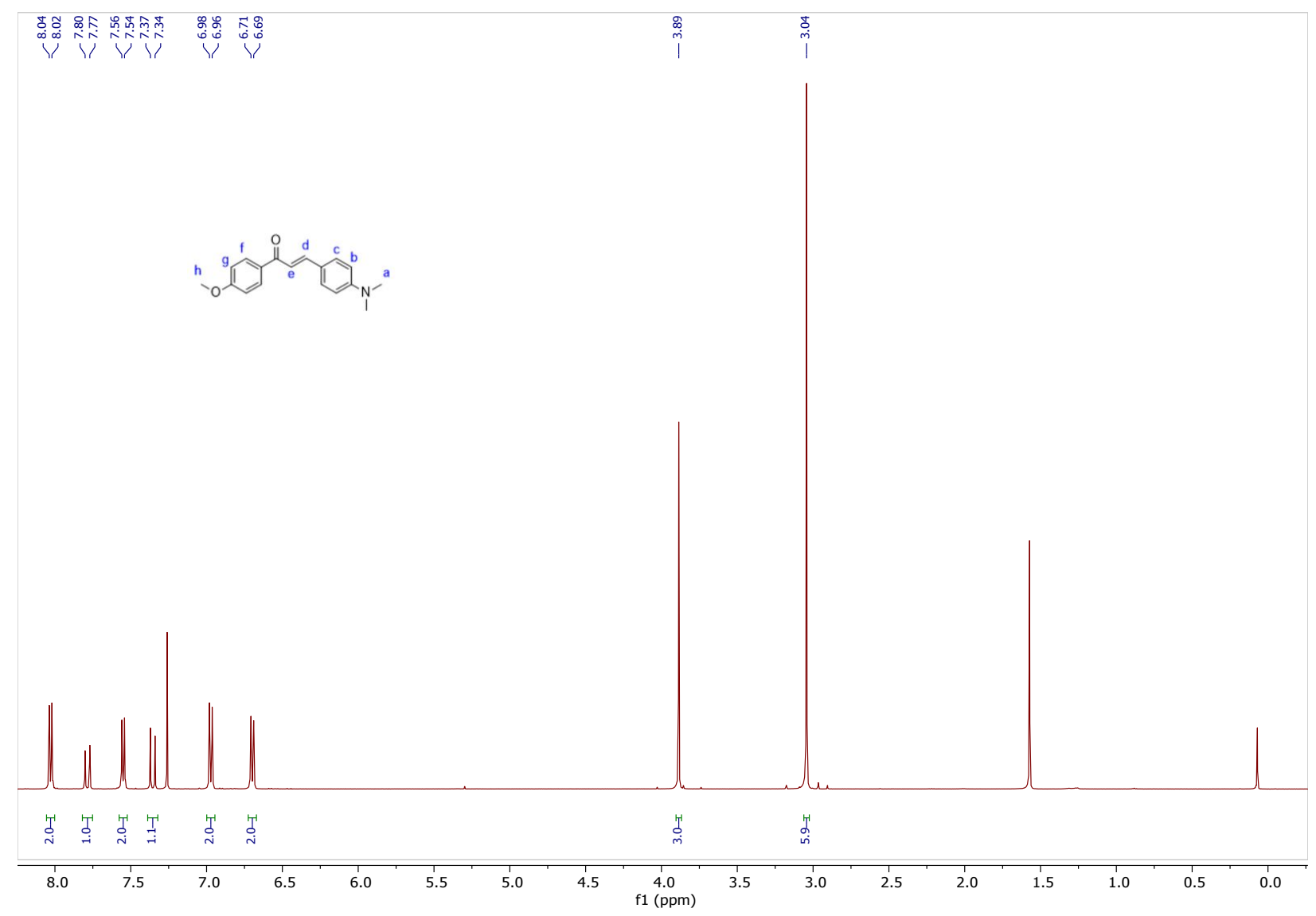

Figure S2: ${ }^{1} \mathrm{H}$ NMR $1\left(500 \mathrm{MHz}, 298 \mathrm{~K}, \mathrm{CDCl}_{3}\right)$ 
Compound (3): The chalcone 1 (4.01 g, $14.3 \mathrm{mmol}, 1 \mathrm{eq}$ ) was suspended in $60 \mathrm{~mL}$ of $\mathrm{MeOH}$ in a $500 \mathrm{~mL}$ round bottom flask. Diethylamine $(8.85 \mathrm{~mL}, 85.6 \mathrm{mmol}, 6 \mathrm{eq})$ and nitromethane $(9.23 \mathrm{~mL}, 172.4 \mathrm{mmol}, 12 \mathrm{eq})$ were added, and the reaction was refluxed overnight. The solvents were then evaporated under vacuum to yield the target compound as a thick, sticky yellow-brown liquid corresponding to crude 2 , which was directly engaged in the next reaction without further purification or characterization. The resulting crude 2 was dissolved in $120 \mathrm{~mL}$ of EtOH. $\mathrm{NH}_{4} \mathrm{OAc}(13.80 \mathrm{~g}, 179.0 \mathrm{mmol}, 12.5 \mathrm{eq})$ was added and the suspension was refluxed overnight. Upon completion the solvents were evaporated to $1 / 4^{\text {th }}$ of the initial volume and transferred into Falcon centrifugation tubes. The mixture was centrifuged, the supernatant was discarded and the base was resuspended in EtOH. The process was repeated until the discarded supernatant came blue and the solid residue exhibits a clean, glossy surface. The solid was transferred into a round bottom flask and dried under vacuum to isolate the corresponding aza-dipyrromethene 3 as a dark blue solid ( $1.79 \mathrm{~g}, 42 \%$ yield over two steps).

${ }^{1} \mathrm{H}$ NMR $\left(500 \mathrm{MHz}, 298 \mathrm{~K}, \mathrm{CDCl}_{3}\right) \delta(\mathrm{ppm})=3.04\left(\mathrm{~s}, 12 \mathrm{H}, \mathrm{H}_{\mathrm{a}}\right), 3.91\left(\mathrm{~s}, 6 \mathrm{H}, \mathrm{H}_{\mathrm{g}}\right), 6.79(\mathrm{~d}, J=$ $\left.8.9 \mathrm{~Hz}, 4 \mathrm{H}, \mathrm{H}_{\mathrm{b}}\right), 6.99\left(\mathrm{~s}, 2 \mathrm{H}, \mathrm{H}_{\mathrm{d}}\right), 7.04\left(\mathrm{~d}, J=8.8 \mathrm{~Hz}, 4 \mathrm{H}, \mathrm{H}_{\mathrm{f}}\right), 7.89\left(\mathrm{~d}, J=8.8 \mathrm{~Hz}, 4 \mathrm{H}, \mathrm{H}_{\mathrm{c}}\right), 8.05$ (d, J = 8.9 Hz, 4H, $\mathrm{H}_{\mathrm{e}}$ ).

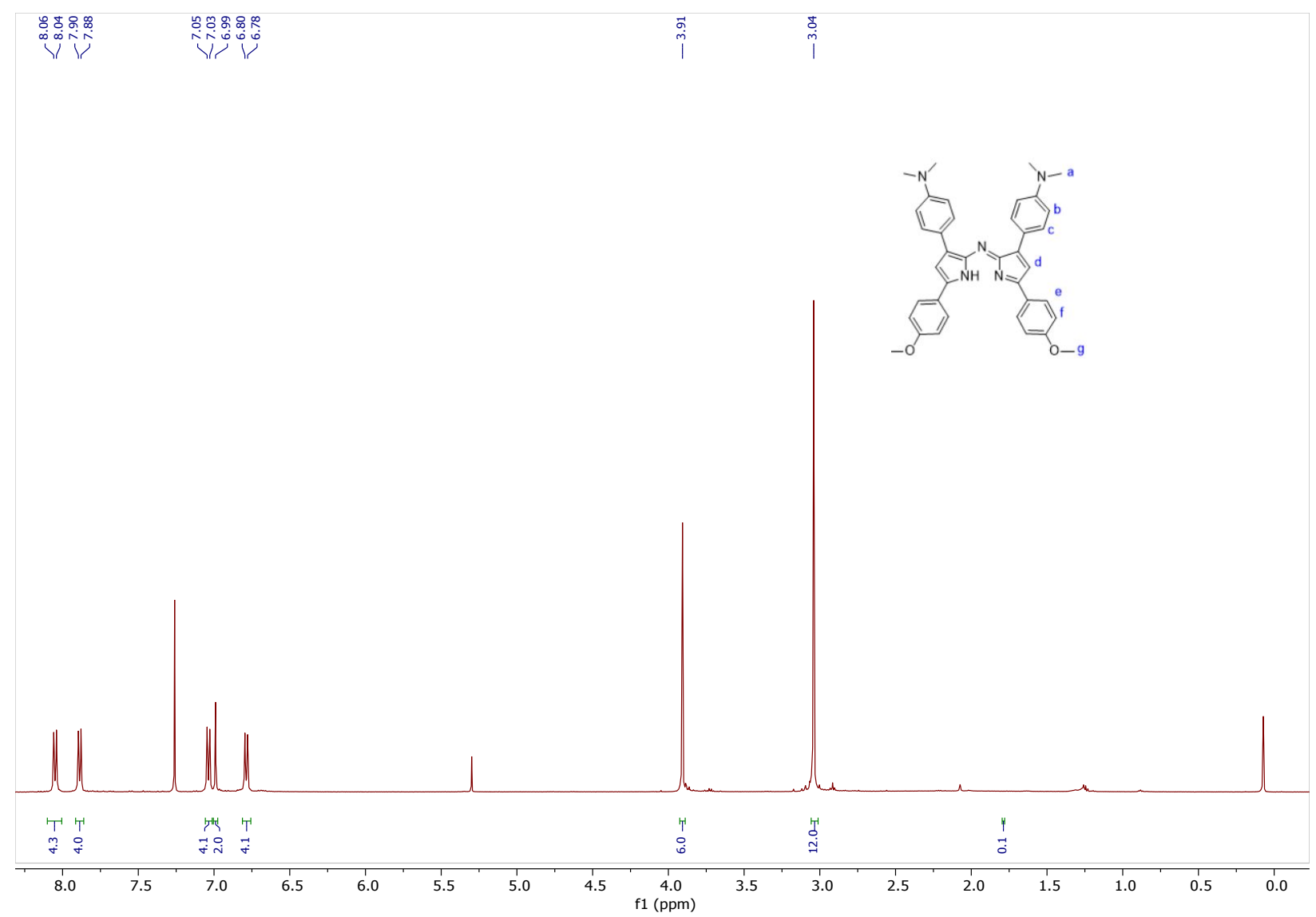

Figure S3: ${ }^{1} \mathrm{H}$ NMR $3\left(500 \mathrm{MHz}, 298 \mathrm{~K}, \mathrm{CDCl}_{3}\right)$ 
Compound aza-SWIR-01: Azadipyrromethene (3,1.74 g, 1 eq) were dissolved in $110 \mathrm{~mL}$ of dry THF in a $500 \mathrm{~mL}$ round bottom flask under argon. DIPEA $(5.50 \mathrm{~mL}, 32.4 \mathrm{mmol}, 11 \mathrm{eq})$ were added and the reaction was stirred for $15 \mathrm{~min}$ at room temperature. $\mathrm{BF}_{3}{ }^{*} \mathrm{Et}_{2} \mathrm{O}(5.50 \mathrm{~mL}$, $44.6 \mathrm{mmol}, 10 \mathrm{eq}$ ) were added and the mixture was heated to reflux for $24 \mathrm{~h}$. Upon completion, the reaction mixture was evaporated to dryness. The product was solubilized in $80 \mathrm{~mL}$ of DCM and $20 \mathrm{~mL}$ of $\mathrm{MeOH}$. DCM was gradually evaporated to replace by full $\mathrm{MeOH}$. The solid was then decanted and the supernatant was removed. The obtained precipitate was resuspended in $\mathrm{MeOH}$ and the operation was repeated until the initially green supernatant took a blue color. The crude product was washed with $\mathrm{Et}_{2} \mathrm{O}(2 \times 20 \mathrm{~mL})$ and pentane $(2 \times 20 \mathrm{~mL})$ and dried to obtain the corresponding pure aza-SWIR-01 as a fine crystalline violet powder $(1.17 \mathrm{~g}, 62 \%$ yield).

${ }^{1} \mathrm{H}$ NMR $\left(500 \mathrm{MHz}, 298 \mathrm{~K}, \mathrm{CDCl}_{3}\right) \delta(\mathrm{ppm})=3.08\left(\mathrm{~s}, 12 \mathrm{H}, \mathrm{H}_{\mathrm{a}}\right), 3.87\left(\mathrm{~s}, 6 \mathrm{H}, \mathrm{H}_{\mathrm{g}}\right), 6.78(\mathrm{~d}, \mathrm{~J}=$ $\left.9.0 \mathrm{~Hz}, 4 \mathrm{H}, \mathrm{H}_{\mathrm{b}}\right), 6.83\left(\mathrm{~s}, 2 \mathrm{H}, \mathrm{H}_{\mathrm{d}}\right), 6.98\left(\mathrm{~d}, J=9.0 \mathrm{~Hz}, 4 \mathrm{H}, \mathrm{H}_{\mathrm{f}}\right.$ ), $8.04\left(\mathrm{~d}, J=9.0 \mathrm{~Hz}, 4 \mathrm{H}, \mathrm{H}_{\mathrm{c}}\right.$ ), 8.07 (d, $J=9.0 \mathrm{~Hz}, 4 \mathrm{H}, \mathrm{H}_{\mathrm{e}}$ ).

${ }^{11} \mathrm{~B}$ NMR $\left(160 \mathrm{MHz}, 298 \mathrm{~K}, \mathrm{CDCl}_{3}\right) \delta(\mathrm{ppm})=1.10(\mathrm{t}, J=32.3 \mathrm{~Hz})$.

${ }^{19} \mathrm{~F} \mathrm{NMR}\left(470 \mathrm{MHz}, 298 \mathrm{~K}, \mathrm{CDCl}_{3}\right) \delta(\mathrm{ppm})=-130.57$ (q, $\left.J=32.0 \mathrm{~Hz}\right)$.

HR-MS (ESI): $m / z$ calculated for $\mathrm{C}_{38} \mathrm{H}_{36} \mathrm{BF}_{2} \mathrm{~N}_{5} \mathrm{O}_{2}[\mathrm{M}+\mathrm{H}]^{+}$644.29301 Da; found 644.29938 Da.

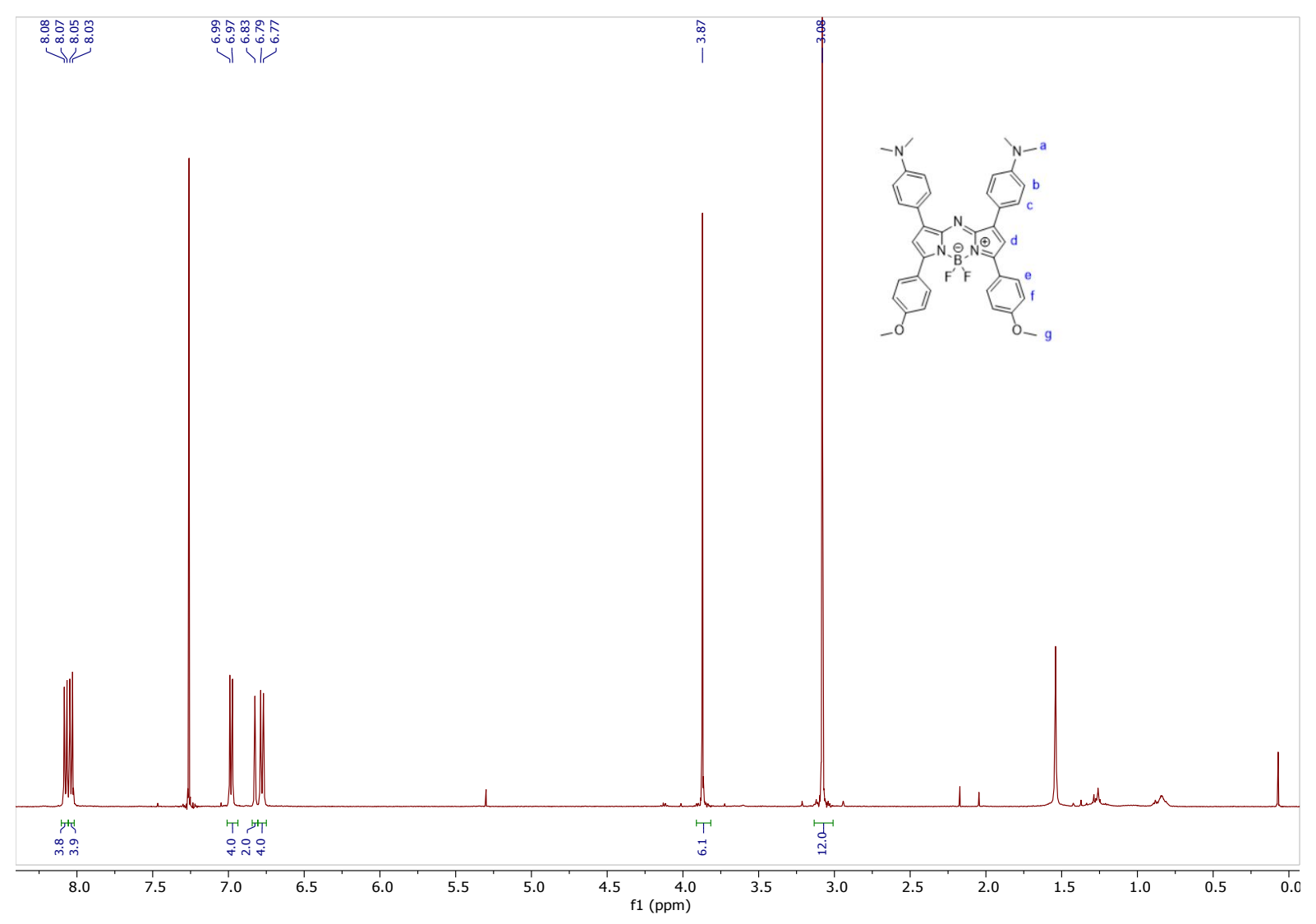

Figure S4: ${ }^{1} \mathrm{H}$ NMR aza-SWIR-01 $\left(500 \mathrm{MHz}, 298 \mathrm{~K}, \mathrm{CDCl}_{3}\right)$ 


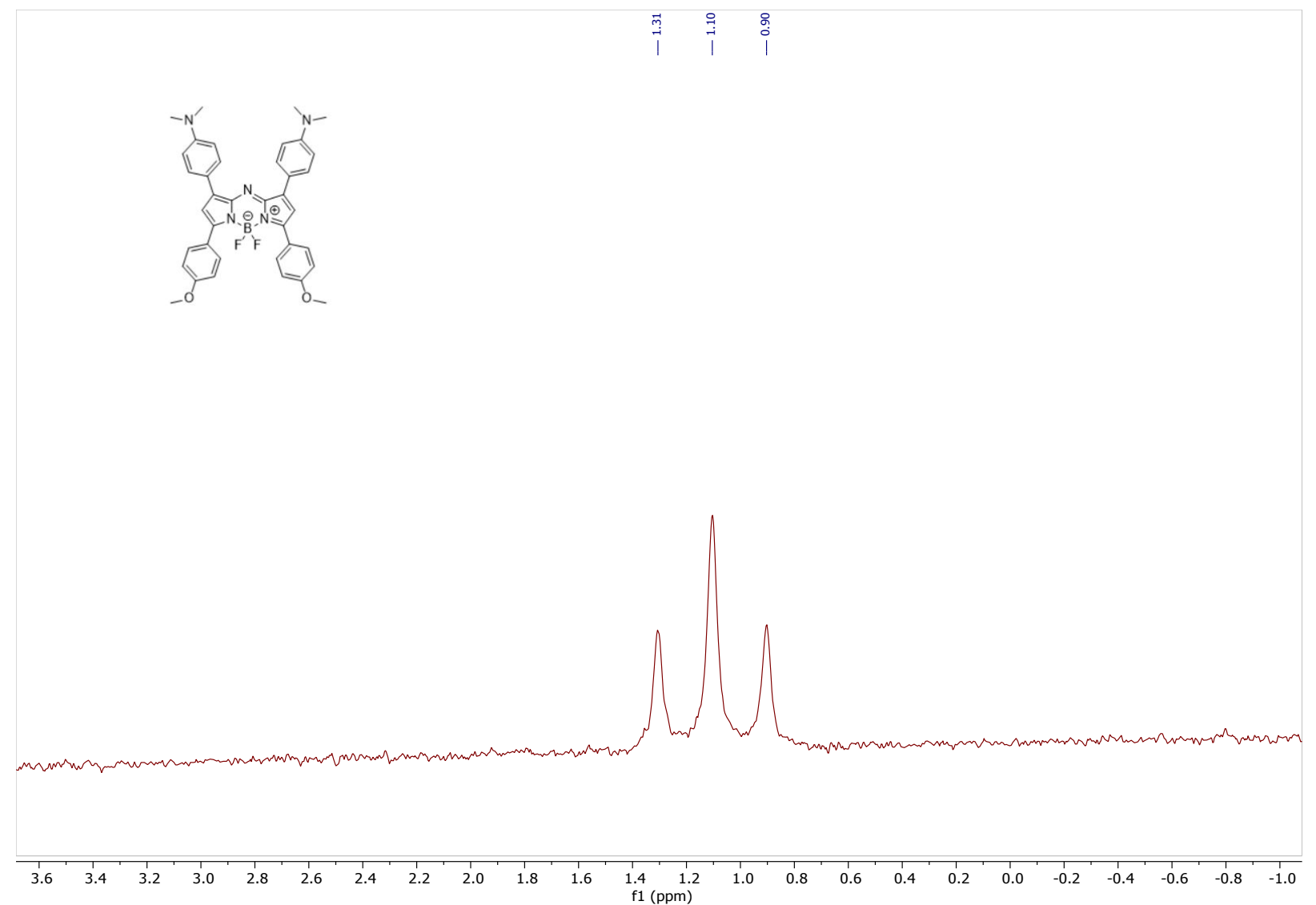

Figure S5: ${ }^{11} \mathrm{~B}$ NMR aza-SWIR-01 $\left(160 \mathrm{MHz}, 298 \mathrm{~K}, \mathrm{CDCl}_{3}\right)$

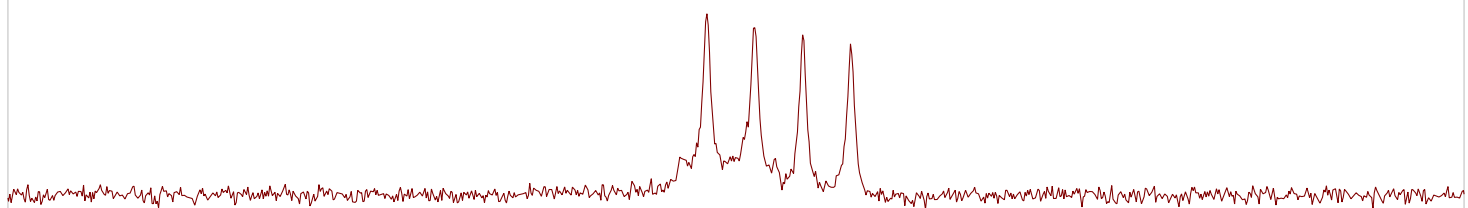

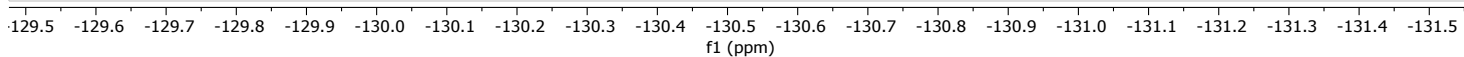

Figure S6: ${ }^{19} \mathrm{~F}$ NMR aza-SWIR-01 (470 MHz, $\left.298 \mathrm{~K}, \mathrm{CDCl}_{3}\right)$ 


\section{Crystal Data and Experimental:}

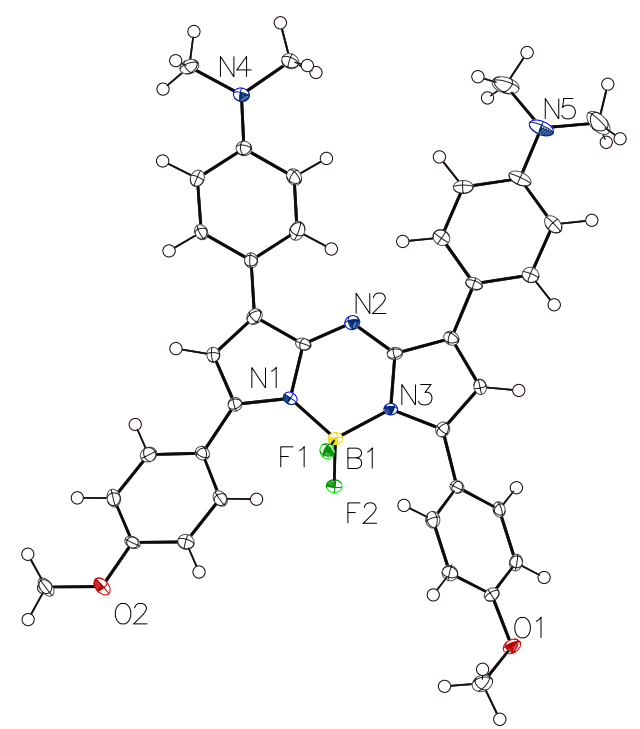

Figure S7: Crystallographic structure of aza-SWIR-01. Thermal ellipsoids are drawn at $50 \%$ probability plot. Solvent and other molecular entity are omitted for clarity.

Experimental. Single metallic dark violet prism-shaped crystals of aza-SWIR-01 were recrystallized from a mixture of DCM and hexane by slow evaporation. A suitable crystal 0.34 $\times 0.12 \times 0.10 \mathrm{~mm}^{3}$ was selected and mounted on a MITIGEN holder oil on a Bruker D8 Venture diffractometer. The crystal was kept at a steady $T=100.0(1) \mathrm{K}$ during data collection. The structure was solved with the ShelXT 2018/2 structure solution program using the Intrinsic Phasing solution method and by using Olex $2^{3}$ as the graphical interface. The model was refined with version $2018 / 3$ of ShelXL using Least Squares minimization ${ }^{4}$.

Crystal Data. $\mathrm{C}_{39} \mathrm{H}_{38} \mathrm{BCl}_{2} \mathrm{~F}_{2} \mathrm{~N}_{5} \mathrm{O}_{2}, M_{r}=728.45$, triclinic, $P-1$ (No. 2), $\mathrm{a}=13.9315(8) \AA$, $\mathrm{b}=$ 16.5505(9) $\AA, \quad c=17.0631(9) \AA, \alpha=116.211(2)^{\circ}, \quad \beta=93.502(2)^{\circ}, \quad \gamma=95.041(2)^{\circ}, \quad V=$ 3494.1(3) $\AA^{3}, T=100.0(1) \mathrm{K}, Z=4, Z^{\prime}=2, \mu\left(M_{0} K_{\alpha}\right)=0.241,63554$ reflections measured, 12281 unique $\left(R_{\text {int }}=0.0896\right)$ which were used in all calculations. The final $w R_{2}$ was 0.1442 (all data) and $R_{1}$ was $0.0531(\mathrm{I}>2(\mathrm{I}))$. 
Table S1: Crystallographic information.

\begin{tabular}{|c|c|}
\hline Compound & aza-SWIR-01 \\
\hline CCDC & 1977285 \\
\hline Formula & $\mathrm{C}_{39} \mathrm{H}_{38} \mathrm{BCl}_{2} \mathrm{~F}_{2} \mathrm{~N}_{5} \mathrm{O}_{2}$ \\
\hline$D_{\text {calc }} / \mathrm{g} \mathrm{cm}^{-3}$ & 1.385 \\
\hline$\mu / \mathrm{mm}^{-1}$ & 0.241 \\
\hline Formula Weight & 728.45 \\
\hline Color & metallic dark violet \\
\hline Shape & prism \\
\hline Size $/ \mathrm{mm}^{3}$ & $0.34 \times 0.12 \times 0.10$ \\
\hline$T / \mathrm{K}$ & 100.0(1) \\
\hline Crystal System & triclinic \\
\hline Space Group & $P-1$ \\
\hline$a / \AA$ & $13.9315(8)$ \\
\hline$b / \AA ̊$ & $16.5505(9)$ \\
\hline$c / \AA$ & $17.0631(9)$ \\
\hline$\alpha l^{\circ}$ & $116.211(2)$ \\
\hline$\beta l^{\circ}$ & $93.502(2)$ \\
\hline$y^{\circ}$ & $95.041(2)$ \\
\hline $\mathrm{V} / \AA^{3}$ & $3494.1(3)$ \\
\hline Z & 4 \\
\hline$Z^{\prime}$ & 2 \\
\hline Wavelength/Å & 0.710760 \\
\hline Radiation type & $\mathrm{MoK}_{\alpha}$ \\
\hline$\Theta_{\min } I^{\circ}$ & 2.857 \\
\hline$\Theta_{\max } 1^{\circ}$ & 25.000 \\
\hline Measured Refl. & 63554 \\
\hline Independent Refl. & 12281 \\
\hline $\begin{array}{l}\text { Reflections with I > } \\
2(\mathrm{I})\end{array}$ & 7507 \\
\hline$R_{i n t}$ & 0.0896 \\
\hline Parameters & 931 \\
\hline Restraints & 0 \\
\hline Largest Peak & 1.012 \\
\hline Deepest Hole & -1.028 \\
\hline GooF & 1.009 \\
\hline$w R_{2}$ (all data) & 0.1442 \\
\hline$w R_{2}$ & 0.1216 \\
\hline$R_{1}$ (all data) & 0.1017 \\
\hline$R_{1}$ & 0.0531 \\
\hline
\end{tabular}

Structure Quality Indicators

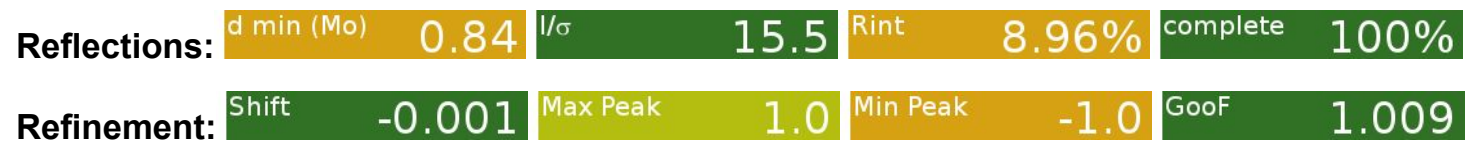

Data were measured using $\phi$ and $\omega$ scans using $\mathrm{MoK}_{\alpha}$ radiation. The total number of runs and images was based on the strategy calculation from the program APEX ${ }^{5}$. The maximum resolution that was achieved was $\Theta=25^{\circ}(0.84 \AA)$. The diffraction pattern was indexed. The total number of runs and images was based on the strategy calculation from the program APEX3 ${ }^{5}$ and the unit cell was refined using SAINT (Bruker, V8.38A, after 2013) on 9994 
reflections, $16 \%$ of the observed reflections. Data reduction, scaling and absorption corrections were performed using SAINT ${ }^{5}$. The final completeness was $99.80 \%$ out to $25^{\circ}$ in $\Theta$. A multiscan absorption correction was performed using SADABS-2016/2 was used for absorption correction. $w R_{2}$ (int) was 0.0737 before and 0.0617 after correction. The ratio of minimum to maximum transmission was 0.7787 . The absorption coefficient $\mu$ of this material was 0.241 $\mathrm{mm}^{-1}$ at this wavelength $(\lambda=0.711 \AA)$ and the minimum and maximum transmissions were 0.756 and 0.971 . The structure was solved and the space group $P-1$ (\# 2) determined by the ShelXT 2018/2 structure solution program using the Intrinsic Phasing solution methods and refined by Least Squares using version $2018 / 3$ of ShelXL ${ }^{6}$. All non-hydrogen atoms were refined anisotropically. Hydrogen atom positions were calculated geometrically and refined using the riding model. Hydrogen atom positions were calculated geometrically and refined using the riding model. The value of $Z^{\prime}$ was 2 . This means that there were two independent molecules in the asymmetric unit with one DCM solvent molecule. Data CCDC-1977285 contain the supplementary crystallographic data for this paper. These data can be obtained free of charge from The Cambridge Crystallographic Data Centre via www.ccdc.cam.ac.uk/data_request/cif.

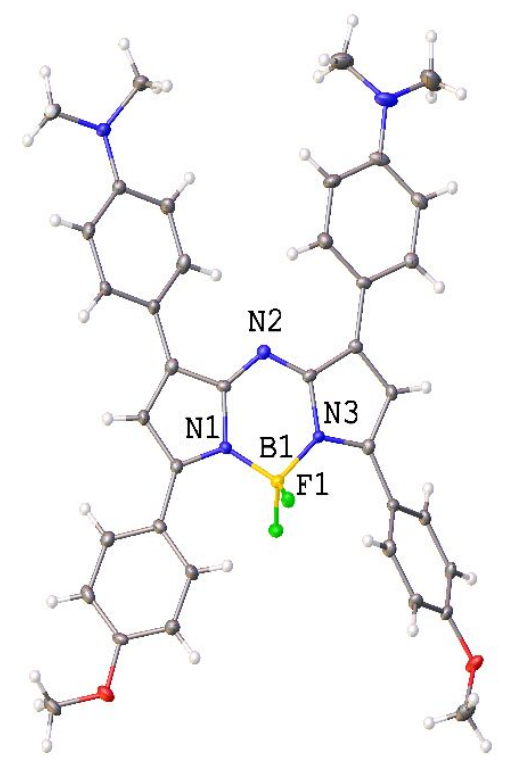

Figure S8: View of one molecular fragment without solvent of aza-SWIR-01 
Compound 4: $N, N$-dimethylpropargylamine $(164 \mu \mathrm{L}, 1.4 \mathrm{mmol}, 2 \mathrm{eq})$ was dissolved in dry THF $(15 \mathrm{~mL})$ in a schlenk flask under argon. Ethylmagnesium bromide $(1.60 \mathrm{~mL}, 1.6 \mathrm{mmol}, 2.2 \mathrm{eq})$ was added and the mixture heated to reflux during $45 \mathrm{~min}$. In parallel, aza-SWIR-01 (455 mg, $0.7 \mathrm{mmol}, 1 \mathrm{eq})$ was dissolved in dry THF $(15 \mathrm{~mL})$ in a second schlenk flask under argon. The first schlenk was then cannuled in the second one and the resulting mixture was heated to reflux for $45 \mathrm{~min}$. Upon completion, the reaction was quenched with $20 \mathrm{~mL}$ of $\mathrm{EtOH}$ and evaporated to dryness. The crude product was then purified by column chromatography on silica gel eluted with $100 \%$ ethyl acetate followed by $\mathrm{DCM} / \mathrm{MeOH}(98 / 2)$ to obtained the corresponding pure product as a fine crystalline violet powder $(451 \mathrm{mg}, 83 \%$ yield).

${ }^{1} \mathrm{H}$ NMR $\left(500 \mathrm{MHz}, 298 \mathrm{~K}, \mathrm{CDCl}_{3}\right) \delta(\mathrm{ppm})=2.17\left(\mathrm{~s}, 12 \mathrm{H}, \mathrm{H}_{\mathrm{i}}\right), 3.08\left(\mathrm{~s}, 12 \mathrm{H}, \mathrm{H}_{\mathrm{a}}\right), 3.15(\mathrm{~s}, 4 \mathrm{H}$, $\left.\mathrm{H}_{\mathrm{h}}\right), 3.85\left(\mathrm{~s}, 6 \mathrm{H}, \mathrm{H}_{\mathrm{g}}\right), 6.76\left(\mathrm{~s}, 2 \mathrm{H}, \mathrm{H}_{\mathrm{d}}\right), 6.77\left(\mathrm{~d}, J=8.9 \mathrm{~Hz}, 4 \mathrm{H}, \mathrm{H}_{\mathrm{b}}\right), 6.95\left(\mathrm{~d}, J=8.9 \mathrm{~Hz}, 4 \mathrm{H}, \mathrm{H}_{\mathrm{f}}\right.$ ), $8.05\left(\mathrm{~d}, J=8.9 \mathrm{~Hz}, 4 \mathrm{H}, \mathrm{H}_{\mathrm{c}}\right), 8.22\left(\mathrm{~d}, J=8.9 \mathrm{~Hz}, 4 \mathrm{H}, \mathrm{H}_{\mathrm{e}}\right)$.

${ }^{13} \mathrm{C}$ NMR $\{1 \mathrm{H}\}\left(\mathrm{CDCl}_{3}, 298 \mathrm{~K}, 150 \mathrm{MHz}\right) \delta(\mathrm{ppm}): 160.7 ; 156.5 ; 150.8 ; 143.0 ; 142.4 ; 131.9$; $130.5 ; 125.6 ; 121.0 ; 115.6 ; 113.2 ; 111.8 ; 55.4 ; 48.0 ; 42.3 ; 40.1$.

HR-MS (ESI): $m / z$ calculated for $\mathrm{C}_{48} \mathrm{H}_{52} \mathrm{BN}_{7} \mathrm{O}_{2}[\mathrm{M}+\mathrm{H}]^{+} 770.42755 \mathrm{Da}$; found $770.43559 \mathrm{Da}$. Analytical HPLC: $\mathrm{Tr}=4.46 \mathrm{~min}$.

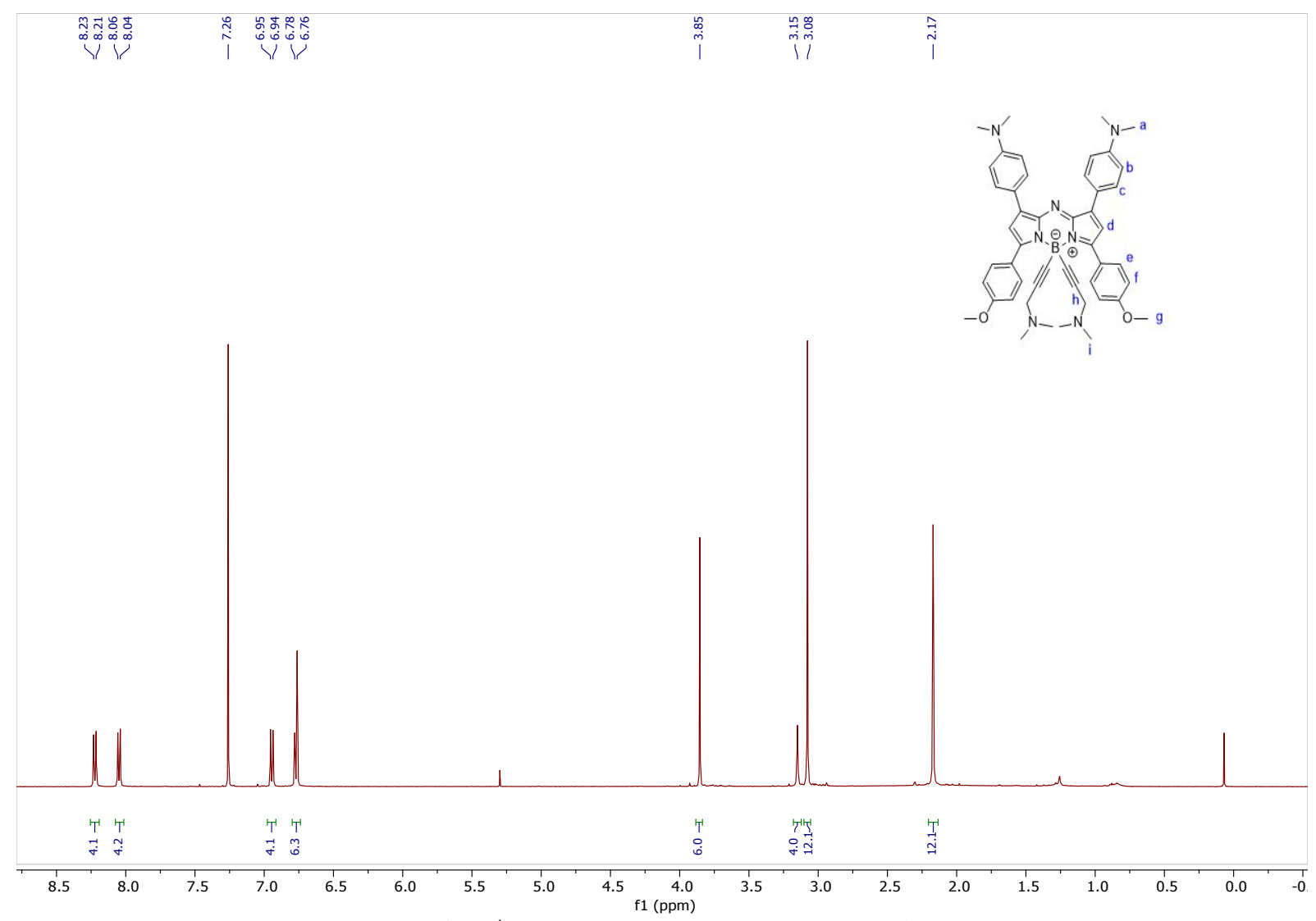

Figure S9: ${ }^{1} \mathrm{H}$ NMR $4\left(500 \mathrm{MHz}, 298 \mathrm{~K}, \mathrm{CDCl}_{3}\right)$ 

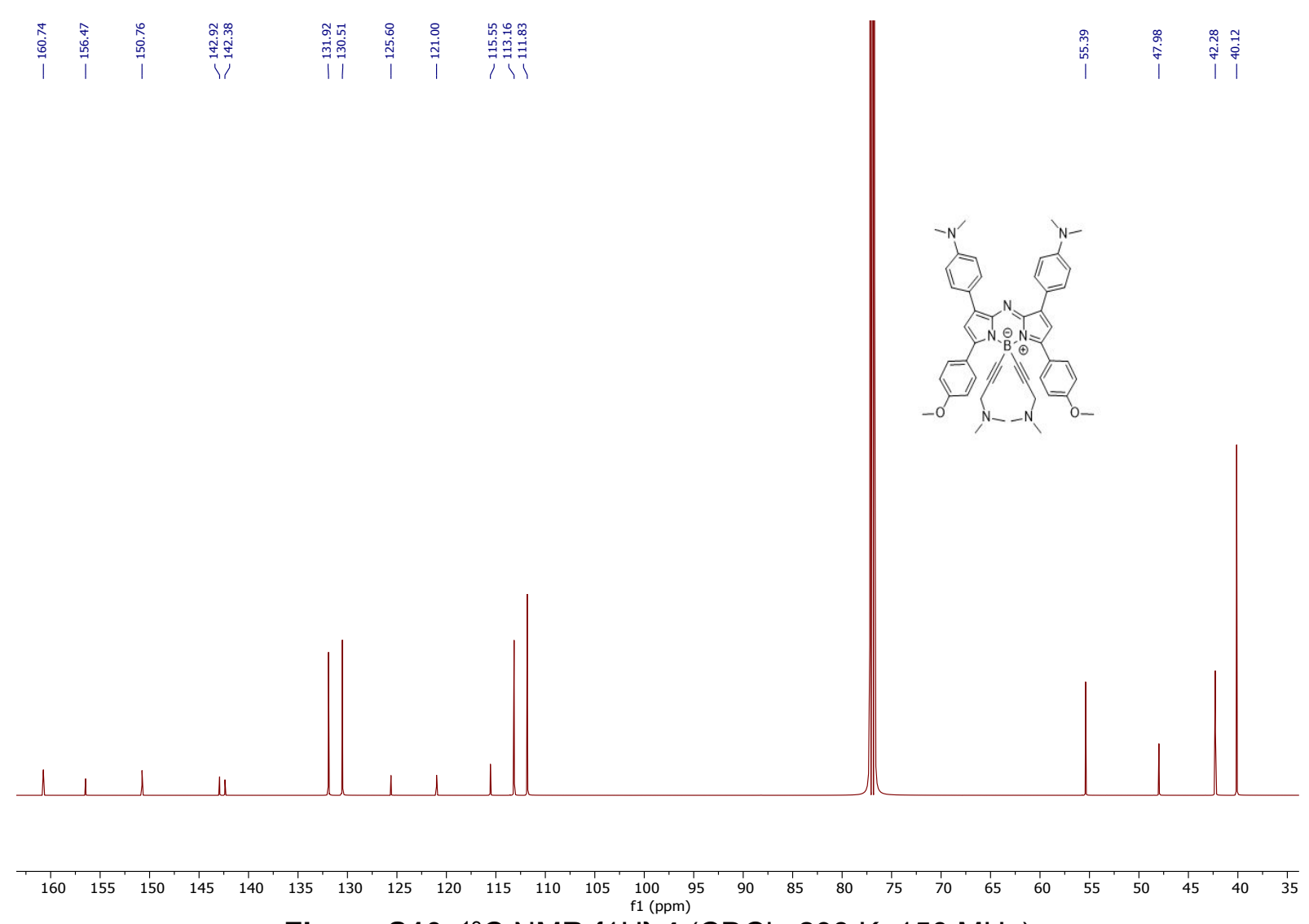

Figure S10: ${ }^{13} \mathrm{C}$ NMR $\{1 \mathrm{H}\} 4\left(\mathrm{CDCl}_{3}, 298 \mathrm{~K}, 150 \mathrm{MHz}\right)$

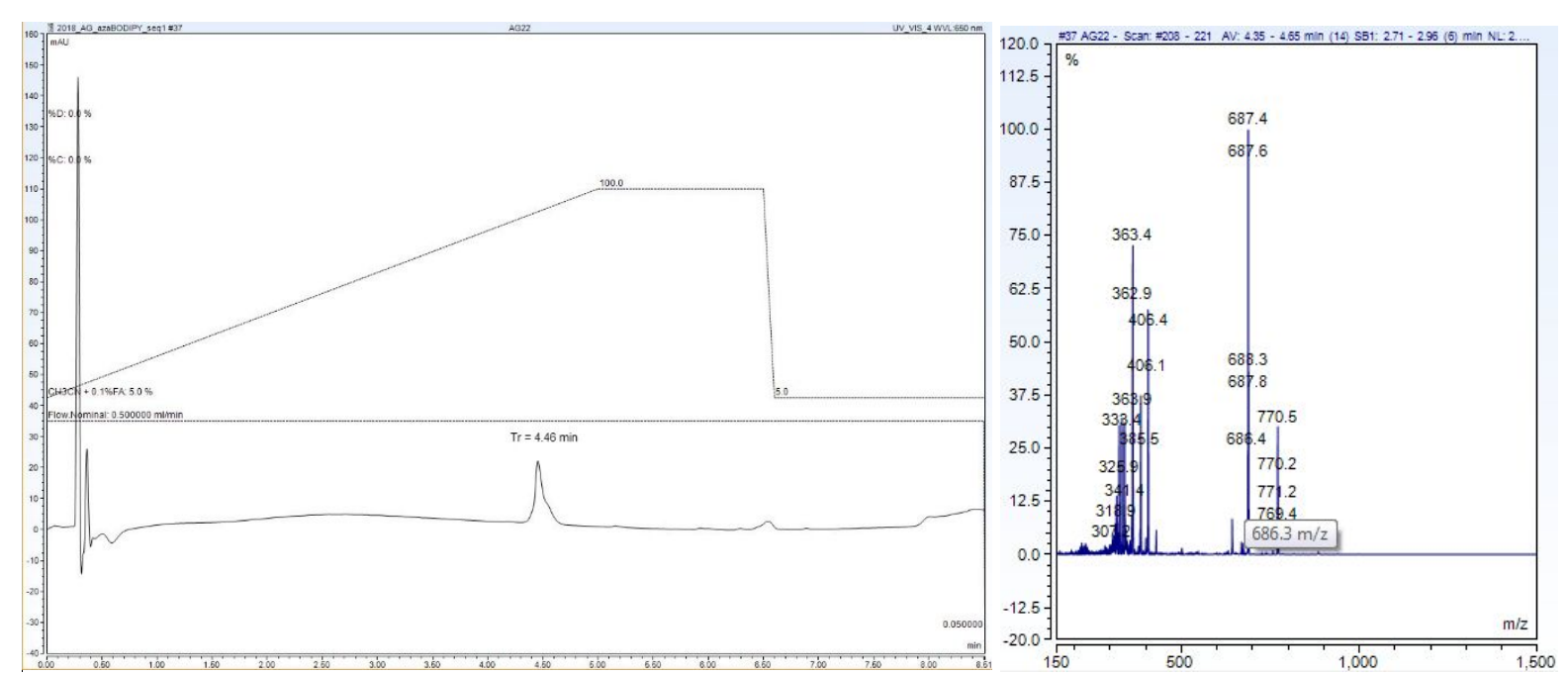

Figure S11: Analytical HPLC 4 
SWIR-WAZABY-01: Compound 4 (30 mg, $0.04 \mathrm{mmol}, 1 \mathrm{eq}$ ) was dissolved in $3 \mathrm{~mL}$ of DCM in a $10 \mathrm{~mL}$ round bottom flask. lodomethane $(1.5 \mathrm{~mL}, 16.1 \mathrm{mmol}, 402 \mathrm{eq})$ was added and the mixture stirred for $15 \mathrm{~min}$ at room temperature. The solvents were evaporated to dryness and the product was portioned between $\mathrm{CH}_{2} \mathrm{Cl}_{2}(5 \mathrm{~mL})$ and water $(5 \mathrm{~mL})$. The organic layer was washed with water $(6 \times 10 \mathrm{~mL})$ and the combined aqueous fractions were evaporated to dryness. The crude product was then purified by semi preparative HPLC and lyophilized to obtain the SWIR-WAZABY-01 product as a blue solid (18 $\mathrm{mg}, 44 \%$ yield).

${ }^{1} \mathrm{H}$ NMR $\left(500 \mathrm{MHz}, \mathrm{DMSO}-\mathrm{d}_{6}\right) \delta(\mathrm{ppm})=2.78\left(\mathrm{~s}, 18 \mathrm{H}, \mathrm{H}_{\mathrm{i}}\right), 3.07\left(\mathrm{~s}, 12 \mathrm{H}, \mathrm{H}_{\mathrm{a}}\right), 3.85\left(\mathrm{~s}, 6 \mathrm{H}, \mathrm{H}_{\mathrm{g}}\right)$, $4.00\left(\mathrm{~s}, 4 \mathrm{H}, \mathrm{H}_{\mathrm{h}}\right), 6.86\left(\mathrm{~d}, J=9.2 \mathrm{~Hz}, 4 \mathrm{H}, \mathrm{H}_{\mathrm{b}}\right), 7.11\left(\mathrm{~d}, J=9.0 \mathrm{~Hz}, 4 \mathrm{H}, \mathrm{H}_{\mathrm{f}}\right), 7.22\left(\mathrm{~s}, 2 \mathrm{H}, \mathrm{H}_{\mathrm{d}}\right), 8.10$ (d, J = 8.9 Hz, 4H, $\left.\mathrm{H}_{\mathrm{c}}\right), 8.24\left(\mathrm{~d}, J=8.9 \mathrm{~Hz}, 4 \mathrm{H}, \mathrm{H}_{\mathrm{e}}\right.$ ).

HR-MS (ESI): $m / z=:$ calculated for $\mathrm{C}_{50} \mathrm{H}_{58} \mathrm{BN}_{7} \mathrm{O}_{2}{ }^{2+}[\mathrm{M}]^{2+} 399.73670$ Th; found 399.73869 Th. Analytical HPLC: $\mathrm{Tr}=4.49 \mathrm{~min}$.

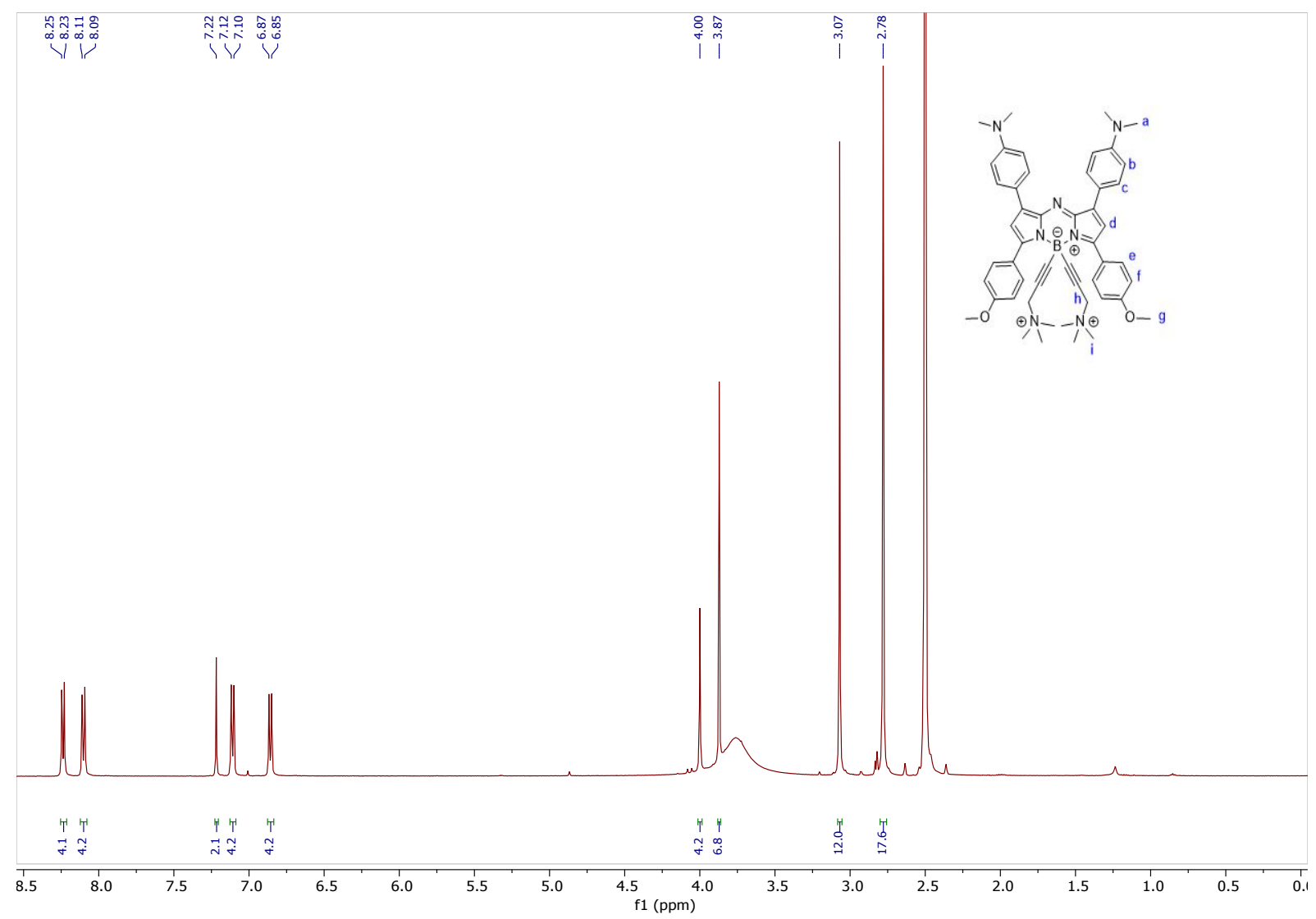

Figure S12: ${ }^{1} \mathrm{H}$ NMR SWIR-WAZABY-01 (500 MHz, $\left.298 \mathrm{~K}, \mathrm{DMSO}^{-\mathrm{d}_{6}}\right)$ 

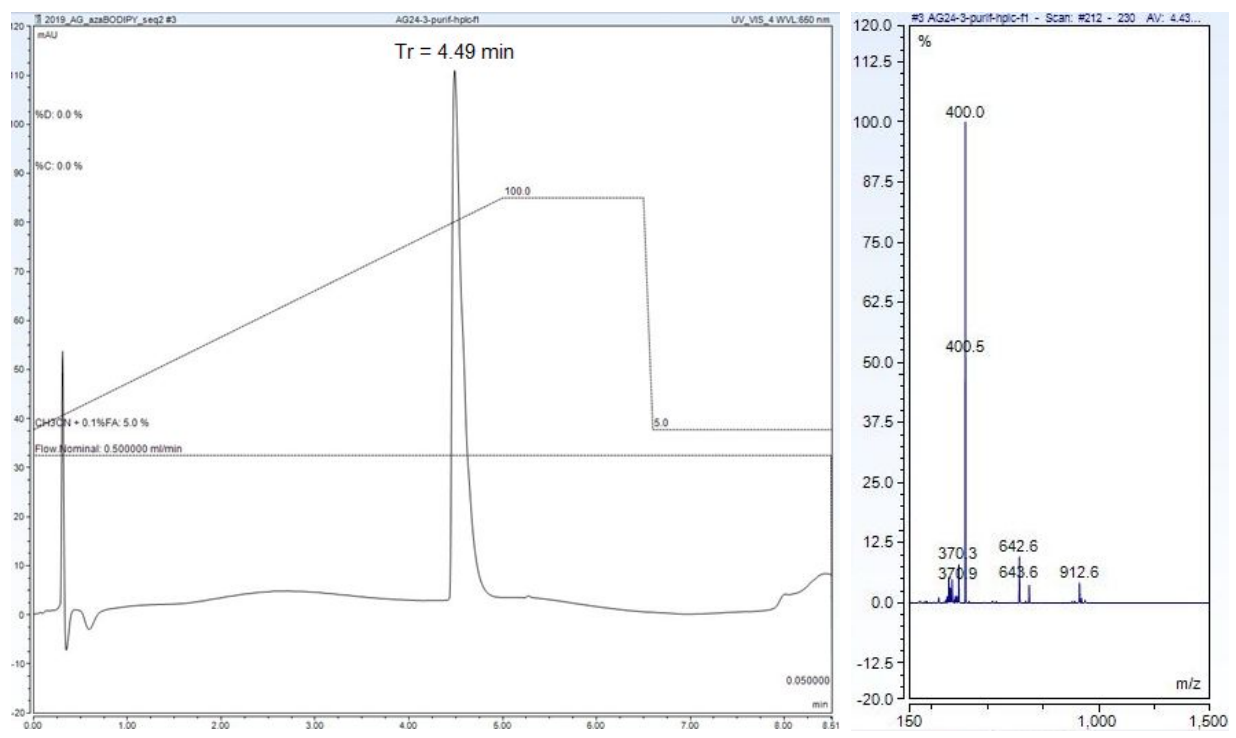

Figure S13: Analytical HPLC SWIR-WAZABY-01 
Photophysical characterization:

Absorbance measurements were recorded on a UV-Vis-NIR spectrophotometer Cary5000 between 300 and 1,200 $\mathrm{nm}$. Steady-state photoluminescence spectra were measured from 700 to $1,500 \mathrm{~nm}$ with a calibrated FSP 920 (Edinburgh Instruments, Edinburgh, United Kingdom) spectrofluorometer equipped with a nitrogen-cooled PMT R5509P.

Relative measurements of photoluminescence QYs $(\Phi f, x)$ were performed using the dye IR125 dissolved in dimethylsulfoxide (DMSO) as reference. The QY of this dye was previously determined absolutely to $\Phi f, s t=0.23$. The relative $Q Y$ were calculated according to the formula of Demas and Crosby, see equation below.

$$
\Phi_{f, x}=\Phi_{f, s t} \frac{F_{x}}{F_{s t}} \cdot \frac{f_{s t}\left(\lambda_{e x, s t}\right)}{f_{x}\left(\lambda_{e x, x}\right)} \cdot \frac{n_{x}^{2}\left(\lambda_{e x, x}\right)}{n_{s t}^{2}\left(\lambda_{e x, s t}\right)}
$$

The subscripts $x$, st, and ex denote sample, standard, and excitation respectively. $f\left(\lambda \_e x\right)$ is the absorption factor, $F$ the integrated spectral fluorescence photon flux, and $n$ the refractive index of the solvents used (DMSO for IR125 and aza-SWIR-01; 10\% mouse plasma for SWIRWAZABY-01).

All spectroscopic measurements were done in a $1 \mathrm{~cm}$ quartz cuvettes from Hellma $\mathrm{GmbH}$ at room temperature using air-saturated solutions.

Table S2: Photophysical characterization of aza-SWIR-01 in DMSO and SWIR-WAZABY-01 in $10 \%$ plasma.

\begin{tabular}{lccc}
\hline Compound & $\begin{array}{c}\text { Emission } \\
(\mathbf{7 2 3 - 1 , 3 0 0} \mathbf{~ n m})\end{array}$ & $\begin{array}{c}\mathbf{n} \\
\text { (refractive index) }\end{array}$ & $\begin{array}{c}\text { Quantum Yield } \\
\mathbf{( \% )}\end{array}$ \\
\hline IR125 & $32,800,000$ & 1.48 & 23 \\
aza-SWIR-01 & $1,183,000$ & 1.48 & 0.83 \\
SWIR-WAZABY-01 & $4,450,000$ & 1.335 & 2.54 \\
\hline
\end{tabular}

\section{Fluorescence calibration}

Serial dilutions of SWIR-WAZABY-01 were performed in various aqueous media (PBS, $\mathrm{NaCl}$ $0.9 \%$, Glucose $5 \%$ ), BSA $40 \mathrm{~g} / \mathrm{L}$ or mouse plasma, and the fluorescence was recorded from 1,250 to $1,700 \mathrm{~nm}$ (100 ms acquisition signal). Analyses were performed using FIJI software. 


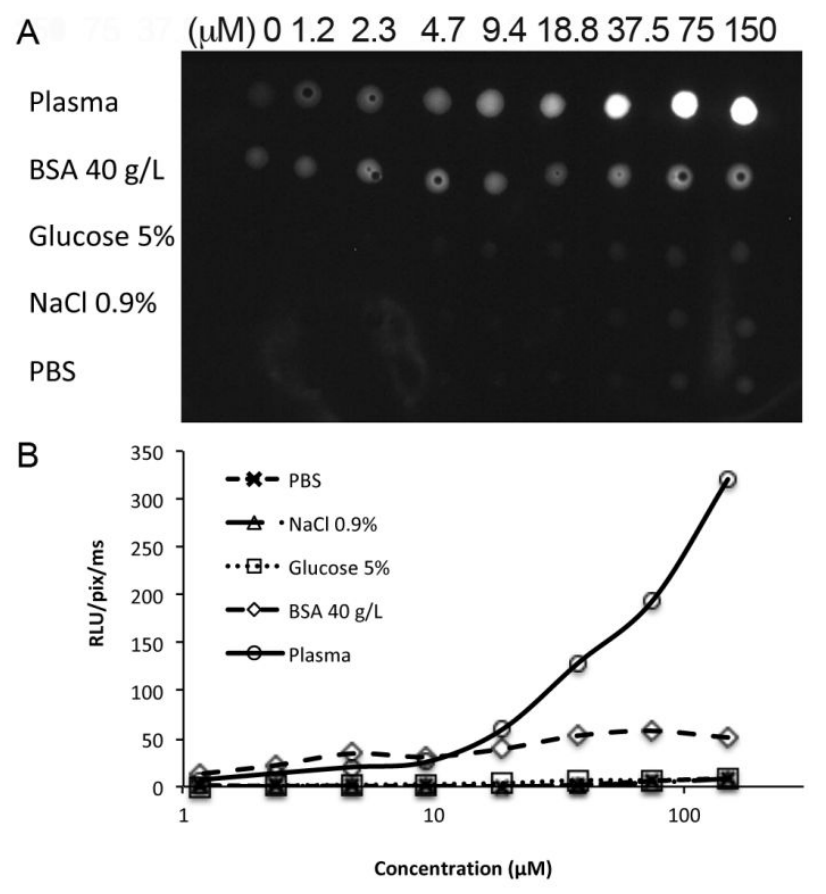

Figure S14: Representative fluorescence of SWIR-WAZABY-01 in various media: (A) SWIR imaging of the drops, and $(B)$ their quantifications. SWIR-WAZABY-01 was moderately fluorescent in BSA $40 \mathrm{~g} / \mathrm{L}$ and highly fluorescent in plasma.
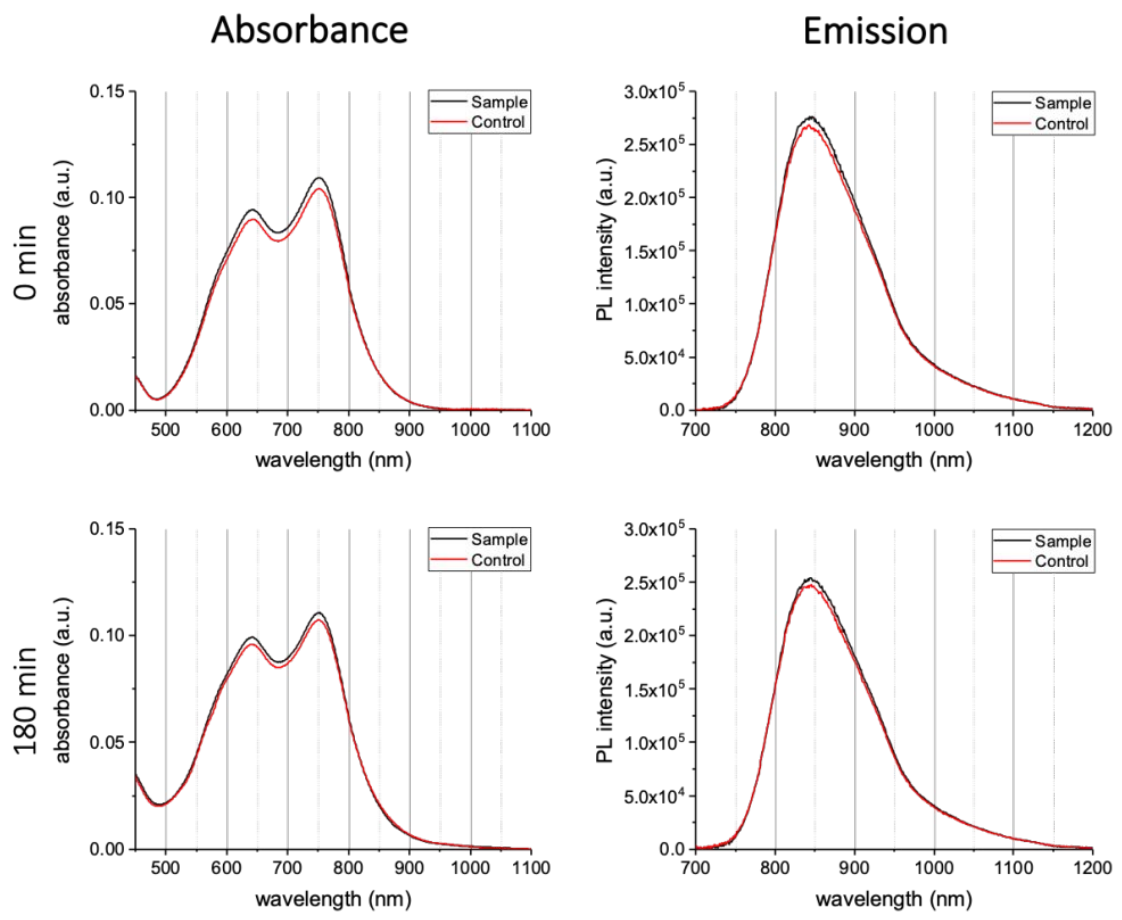

Figure S15: Absorbance and emission spectra of SWIR-WAZABY-01 kept in the dark at room temperature (control) or continuously illuminated (sample) over a period of $180 \mathrm{~min}$ with light of $638 \mathrm{~nm}(1.13 \mathrm{~mW})$. SWIR-WAZABY-01 does not show any signs of significant photobleaching after 180 minutes of illumination under these exemplarily chosen conditions. 


\section{Evaluation of cell toxicity:}

Human healthy cells (renal HEK293 and fibroblast MRC5) and glioblastoma U87MG cells were cultured in appropriated medium enriched with fetal bovine serum before incubation for 72 hours with the indicated concentration of SWIR-WAZABY-01. Cell viability was assessed using MTS assay following the company's instructions (Abcam) and signal was measured at $490 \mathrm{~nm}$, ensuring to avoid any overlap with the SWIR compounds.

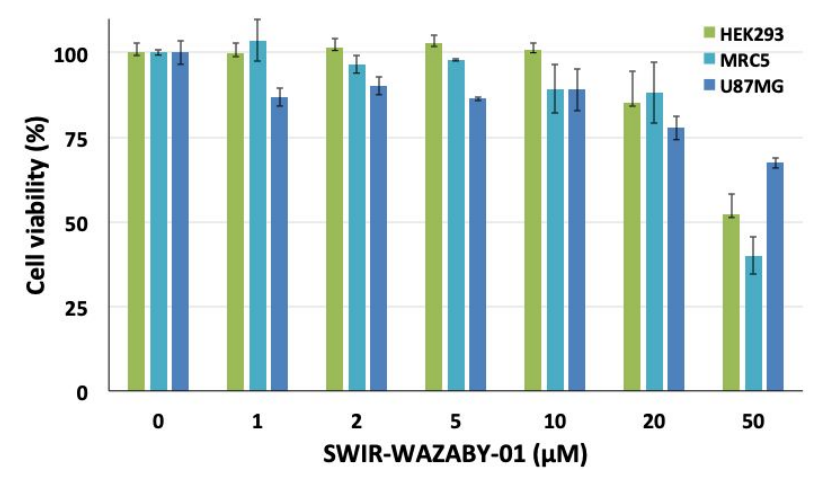

Figure S16: Cell viability of healthy kidney HEK293 and fibroblasts MRC5 cells, and glioblastoma U87MG cells after $72 \mathrm{~h}$ exposure with SWIR-WAZABY-01. The cell viability was assessed by MTS assay.

Mice experiments and pharmacokinetics:

This experimental part was ethically approved by local and national ethics committee following the European Guidelines (APAFIS \#8782-201732813328550 v1). Mice were sub-cutaneously injected with $3 M$ U87MG cells, 3 weeks before imaging. The animals $(n=3 /$ time) were imaged before and at different times after IV administration of $200 \mu \mathrm{L}$ of SWIR-WAZABY-01 $(600 \mu \mathrm{M})$. NIR-II imaging was performed using a Princeton camera 640ST (900-1.700 nm) coupled with a laser excitation source at $\lambda=830 \mathrm{~nm}\left(50 \mathrm{~mW} / \mathrm{cm}^{2}\right)$. A short-pass excitation filter at $1.000 \mathrm{~nm}$ (Thorlabs) was used, in addition of long-pass filters on the SWIR camera from Semrock (LP1.064 nm) and Thorlabs (LP1.250 nm). A $25 \mathrm{~mm}$ lens with 1.4 aperture (Navitar) was used to focus on the samples or mice. After in vivo imaging, organs were sampled for ex vivo analysis. Briefly, the organs were frozen and sections of $7 \mu \mathrm{m}$ were cut and stained with hematoxylin and eosin. Representative histological sections are reported in Figure S16. They indicated the absence of any microscopic change in the liver, kidney and spleen of the animals after a bolus administration of the probe. 

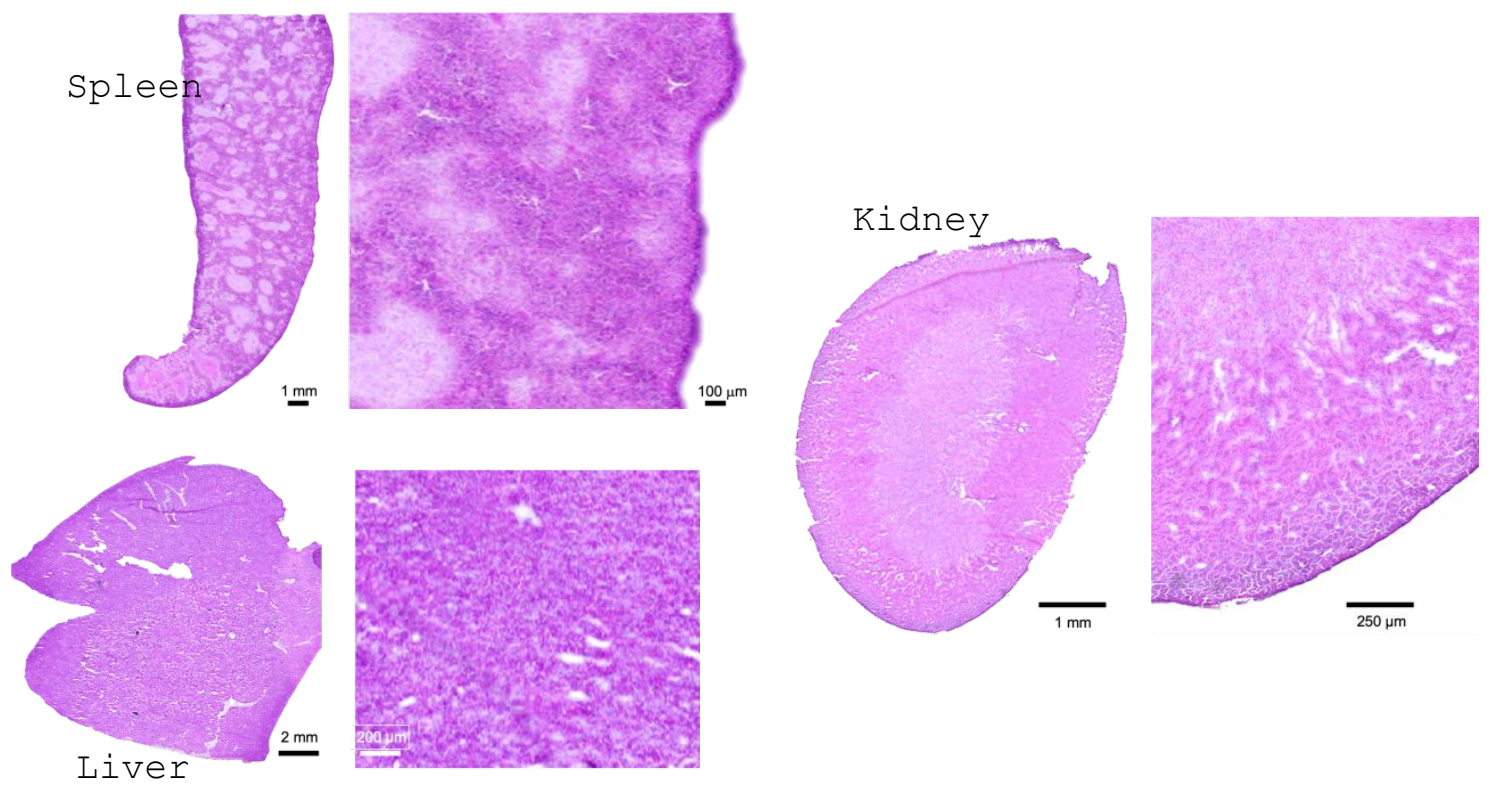

Figure S17: Tissue analysis of spleen, liver and kidney sections, $24 \mathrm{~h}$ after bolus injection of SWIR-WAZABY-01, showed the absence of histological toxicity at the microscopic level.

Mice $(n=3)$ were injected intravenously with $200 \mu \mathrm{L}$ of SWIR-WAZABY-01 (300 $\mu \mathrm{M})$ and blood was collected just after injection and at the following times: 5, 10, 15, 30, 60, 120 and 300 minutes. Blood was centrifuged to sample and quantify the fluorescence in the plasma using the $50 \mathrm{~mm}$ lens and LP1.064 $\mathrm{nm}$. The pharmacokinetic was calculated using Prism software, and fitted with two-phase decay equation.

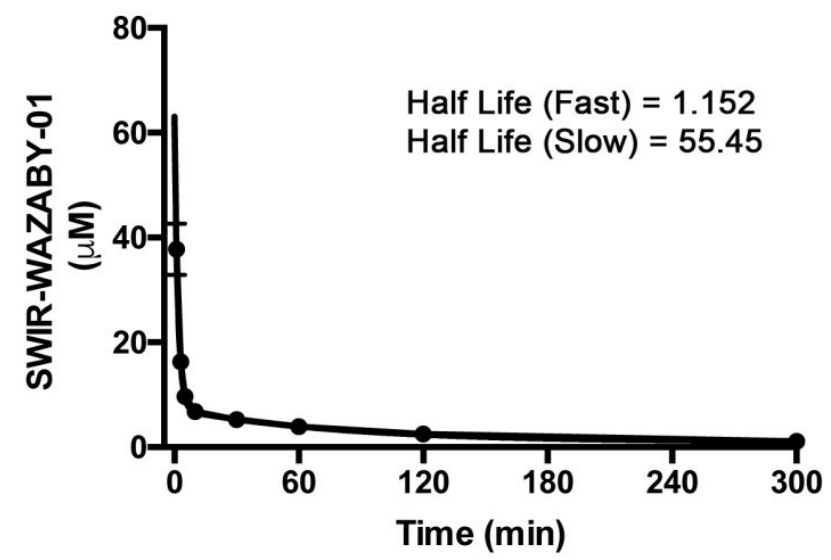

Figure S18: Plasma half-life of SWIR-WAZABY-01 in mice, fitted with two-phase decay equation.

\section{$\underline{\text { References }}$}

1. Jiao, L., Wu, Y., Wang, S., Hu, X., Zhang, P., Yu, C., Cong, K., Meng, Q., Hao, E., Vicente, M. G. (2014) Accessing near-infrared-absorbing BF2-azadipyrromethenes via a push-pull effect. J. Org. Chem. 79, 1830-1835.

2. Pliquett, J., Dubois, A., Racoeur, C., Mabrouk, N., Amor, S., Lescure, R., Bettaieb, A., Collin, B., Bernhard, C., Denat, F., et al. (2019) A Promising Family of Fluorescent Water-Soluble aza-BODIPY Dyes for in Vivo Molecular Imaging. Bioconjug. Chem. 30, 1061-1066. 
3. Dolomanov, O.V., Bourhis, L.J., Gildea, R.J., Howard, J.A.K., Puschmann, H. (2009) Olex2: A complete structure solution, refinement and analysis program. J. Appl. Cryst. 42, 339-341.

4. Sheldrick, G.M. (2015) ShelXT-Integrated space-group and crystal-structure determination. Acta Cryst. A71, 38

5. Bruker, A.X.S., Madison, W.I. Software for the Integration of CCD Detector System Bruker Analytical X-ray Systems, after 2013.

6. Sheldrick, G.M. (2015) Crystal structure refinement with ShelXL, Acta Cryst. C71, 3-8. 